\title{
Susceptibility of Bovine Rotavirus to Interferon
}

\author{
Brief Report
}

\author{
$\mathrm{By}$ \\ L. Dagenais ${ }^{1}$, P.-P. Pastoret ${ }^{1}$, C. Van den Broecke ${ }^{2}$, and J. Werenne 2 \\ 1 Service de Virologie et de Pathologie des Maladies Virales, Faculté de \\ Médecine Vétérinaire de l'Université de Liège, \\ Bruxelles, Belgique \\ 2 Laboratoire de Chimie Générale I, Faculté des Sciences, \\ Université Libre de Bruxelles, \\ Bruxelles, Belgique \\ Accepted September 11, 1981
}

\begin{abstract}
Summary
Using the plaque assay or the CPE test (cytopathogenic effect), we investigated the action of human, simian (rhesus), bovine and murine interferons on bovine rotavirus adapted to grow on established Rhesus monkey kidney cell line (MA 104) or Georgia Bovine Kidney cell line (GBK). Except for the murine interferon we used, which had no antiviral effect at all, the different interferons tested were clearly active.

Three strains of bovine rotavirus were used: a canadian strain PQ (kindly furnished by Dr. M. E. Bégin, St-Hyacinthe, Québec) and strains S14 and S77 isolated in our laboratory. They were grown on MA104 and GBK cells (1). Vesicular Stomatitis Virus (VSV), originally obtained from Dr. Youngner (Pittsburgh), was produced in $\mathrm{L}_{929}$ cells.

Human fibroblast interferon ( $\mathrm{Hu}$ IFN $\beta$ ) was induced in $\mathrm{FS}_{4}$ cells of human foreskin fibroblasts by-poly inosinate-polycytidylate (poly I:C) as described by VILČEK and HAVELL (8) and partially purified by ammonium sulfate precipitation and chromatography on Biogel PI 50 and CM Sephadex as described by KNIGHT (3). The specific activity of the preparation used throughout this work was $1 \times 10^{6}$ international units per $\mathrm{mg}$ of protein.

Mouse fibroblast interferon ( $\mathrm{Mu}$ IFN $\beta$ ) was induced in $\mathrm{L}_{929}$ cells by $\mathrm{NDV}$ virus (Newcastle Disease Virus, Koumaroff strain). The purification of this interferon was achieved according to the method described by PAUCKER and STANCEK (6). Its final specific activity was $1 \times 10^{6}$ international units per mg of protein.

Simian interferon (Rhesus IFN) was induced in MA 104 cells by infecting them with NDV (Koumaroff strain). The crude interferon, treated at $\mathrm{pH} 2$ for at least
\end{abstract}


five days, was used without further purification, after neutralization and clarification by centrifugation.

For the production of bovine interferon (Bov IFN), GBK cells were induced with NDV (Koumaroff strain) and treated as the simian interferon.

The action of interferons on rotavirus was first tested on MA 104 cells using the plaque assay described by Matsuno et al. (5) and Dagenars et al. (2). The cells were established in an antiviral state by incubation with IFN at $37^{\circ} \mathrm{C}$ overnight before inoculation with the bovine rotavirus. Then, the inhibitions by interferons of the cytopathogenic effect provoked either by VSV or by rotavirus were compared by the classical method using MA104 and GBK cells.

According to our results, human, simian and bovine interferons are active on bovine rotavirus grown in established Rhesus monkey kidney or Georgia bovine kidney cell lines, whereas one partially purified murine interferon is not active at all. Compared with VSV, bovine rotavirus does not appear to be less susceptible to bovine interferon as it was reported by La Bonnardière and coworkers (4). The choice of the experimental system is therefore important to ascribe the efficiency of interferon against bovine rotavirus in defined conditions. As the data obtained with the three strains of rotavirus are similar, Table 1 gives the comparison of the susceptibility to interferon of VSV and one strain of rotavirus.

The antiviral activity was destroyed by a pretreatment with trypsin and correlated well with the induction of $2^{\prime} 5^{\prime}$ oligoisoadenylate synthetase (7). This indicates that interferon is the active factor involved in the antiviral effect.

Our preliminary results show that human fibroblast interferon ( $\mathrm{Hu}$ IFN $\beta$ ) has an important heterologous antiviral effect in GBK cells infected with bovine rotavirus. It is therefore worthwhile to test the in vivo effect of human fibroblast interferon (Hu IFN $\beta$ ) on neonatal calf diarrhoea provoked by rotavirus.

Table 1. Activity of different interferons on $M A 104$ and $G B K$ cells on bovine rotavirus (SY7) and VSV multiplications

\begin{tabular}{llccc}
\hline & & \multicolumn{3}{c}{ Interferon } \\
\cline { 4 - 5 } Cell line & Virus & Hu IFN & Rhesus IFN & Bov IFN \\
\hline MA 104 & VSV & 1.00 & 1.00 & 1.00 \\
GBK & VSV & 1.17 & 11.7 & 0.68 \\
MA 104 & Rota. S 77 & 1.39 & 1.39 & 3.76 \\
\hline
\end{tabular}

Figures represent the relative titer of the different interferons in the different systems used, compared to the titer obtained in MA 104 cells using VSV as challenge virus. The mean of two independent determinations are used to establish the comparison. End. points of titration are read as 50 per cent protection against CPE with a technique involving $0.5 \log _{10}$ dilution steps. Reproducible data have been obtained using dilutions of interferon preparations titrating between $10^{2}$ and $10^{4}$ laboratory units/ml

\section{Acknowledgments}

Financial support was provided for by grants from the Institut pour la Recherche Scientifique dans l'Industrie ef l'Agriculture (I.R.S.T.A.). 


\section{References}

1. Dagenats, L., Pastoret, P.-P., Massip, A., Kafekenbeeck, A., Lanstral, B.: Failure to isolate rotavirus from bovine meconium. Vet. Rec. 108, $11-13$ (1981).

2. Dagenais, L., Schwers, A., Pastoret, P.-P., Lerox, P.: Comparison of bovine rotavirus strains by the plaque assay. Vet. Mierobiol. (1981, in press).

3. KNIGHT, E., JR.: Interferon purification and initial characterization from human diplö̈d cells. Proc. Nat. Acad. Sci. (U.S.A.) 73, 520-523 (1976).

4. La Bonnardiere, C., De Vaureix, C., L'Harmon, R., Scherrer, R.: Weak susceptibility of rotavirus to bovine interferon in calf kidney cells. Arch. Virol. 64, $167-170(1980)$.

5. Matsuno, S., Inouye, S., Kono, R.: Plaque assay of neonatal diarrhea virus and the neutralizing antibody in human sera. J. clin. Microbiol. 5, 1-4 (1977).

6. PAUCKer, K., StanceK, D.: Characterization of interferon associated proteins. J. gen. Virol. 15, $129-138(1972)$.

7. VAN DEN Broecke, C., Verhaegen, M., WerenNe, J.: Induction by interferon of $2^{\prime} 5^{\prime}$ A synthetase in heterologous cell systems. Intern. Meeting on the Biol. of Interferon System, Rotterdam, April 1981; 73.

8. VILČEK, J., HAVELL, F. A.: Stabilization of interferon messenger RNA activity by treatment of cells with metabolic inhibitors and lowering of the incubation temperature. Proc. Nat. Acad. Sei. (U.S.A.) 70, 3909-3913 (1973).

Authors' address: Dr. P.-P. Pastoret, Service de Virologie et de Pathologie des Maladies Virales, Faculté de Médecine Vétérinaire de l'Université de Liège, 45, rue des Vétérinaires, 1070 Bruxelles, Belgique.

Received May 29, 1981 